\title{
Sokeri- ja tärkkelyslisäyksen vaikutus säilörehun sulavuu- teen ja typen pidättymiseen pässeillä
}

\author{
Maija-Lissa Salo, Harri Orakoski ja Kaija Suomi \\ Yliopiston kotieläintieteen laitos, Helsinki
}

Saapunut 18.5.1973

\section{Effect of sucrose and starch supplement on the digestibility of grass silage and nitrogen retention in sheep}

Maija-Litsa Salo, Harri Orakoski and Kaija Suomi,

Department of Animal Husbandry, University of Helsinki

\begin{abstract}
The effect of sucrose and starch supplement on the digestibility of grass silage in six sheep (four adult, two still growing) was investigated in two $3 \times 3$ Latin squares. In trial 1 , the silage was supplemented with $0,50 \mathrm{~g}$ or $100 \mathrm{~g}$ sucrose per day, in trial 2 with $0(0), 200 \mathrm{~g}$ sucrose (S) or $200 \mathrm{~g}$ wheat starch (T) per day. The silage rations were reduced to balance the net energy. The carbohydrate supplements amounted to 10,20 or $40 \%$ of the net energy of the rations. A mineral mixture was given to all the sheep. In addition, the $\mathrm{S}$ and $\mathrm{T}$ groups received $15.0 \mathrm{~g}$ casein per day. The crude protein content of the rations was ca. $13-18 \%$ of dry matter for trial 1 , and $15-24 \%$ for trial 2 . The supply of energy slightly exceeded the maintenance requirement.

Sucrose had no appreciable effect on the digestibility of organic matter, hemicellulose and cellulose, nor on the true digestibility of crude protein of silage. No differences between the levels of sucrose were detected.

Starch decreased slightly but not significantly the digestibility of silage.

In trial 2 the nitrogen balance was also determined. Sucrose and starch were equal in this respect and decreased slightly but not significantly the retention of nitrogen.
\end{abstract}

Tulokset helppoliukoisten hiilihydraattien vaikutuksesta rehun sulavuuteen ovat jossakin määrin ristiriitaisia. Yhtäpitävin lienee havainto, että sokeri- (Hamilton 1942, Fontenot ym. 1955, Martin ja Wing 1966) ja tärkkelyslisäys (SwIfT ym. 1947, HEAD 1953) alentaa kuituaineksen sulavuutta ja nimenomaan silloin kun lisätty määrä on suhteellisen suuri (WATSON ym. 1947, Burroughs ym. 1949, Chappell ym. 1968); pieni määrä saattaa sitä jopa nostaa (Chappell ym. 1968, VARner ja Woods 1972). Orgaaniseen aineeseen kokonaisuudessaan ei vaikutus yleensä ole ollut yhtä selvä kuin kuituun: pienen määrän on todettu parantavan (SWIFT ym. 1947, FrederikseN 1971, VARNER ja Woods 1972), suuremman huonontavan sulavuutta (BUR- 
ROUGhS ym. 1949, SyrJäLÄ 1972). Negatiivisen vaikutuksen ovat SwIFT ym. (1947) ja PANDIT ja SINGH (1969) todenneet tärkkelyksellä suuremmaksi kuin sokerilla. Negatiivisen vaikutuksen on toisaalta todettu riippuvan dieetin proteiinipitoisuudesta siten, että huomattavaa sulavuuden alenemista ilmenee vain jos proteiinia on dieetissä niukasti (BURRoughs ym. 1949, 1950).

Typpitasetta useimmat tutkijat mainitsevat sokeri/tärkkelyslisän parantavan (Hamilton 1942, Woods ym. 1956, Chappell ym. 1968, Varner ja WoOds 1972). Dror ym. (1969) on joissakin kokeissa todennut tärkkelyksen huonontavan, SYRJÄLÄ (1972) tärkkelyksen huonontavan, mutta sakkaroosin parantavan.

Tässä tutkimuksessa selviteltiin eri suuruisten sakkaroosilisäysten ja runsaan tärkkelyslisäyksen vaikutusta säilörehun sulavuuteen ja typpitaseeseen pässeillä.

\section{Kokeellinen osa}

Kokeet suoritettiin kuudella pässillä, joista osa oli täysikasvuisia, osa kasvavia. Pässit olivat koehäkeissä ja keruukausien aikana niillä oli koevaljaat. Virtsa valui häkin alla olevaan astiaan. Sekä valmistus- että keruukauden pituus oli yhdeksän päivää.

Kokeet järjestettiin kahden peräkkäisen $3 \times 3$ latinalaisen neliön muotoon. Kokeessa 1 nollaryhmä sai pelkkää säilörehua, määrä vastasi $0.7 \mathrm{ry} / \mathrm{pv}$. Toisella ryhmällä korvattiin noin $10 \%$ energiasta sakkaroosilla, jota pässit saivat $50 \mathrm{~g} / \mathrm{pv}$. Kolmannella ryhmällä sakkaroosin määrä oli $100 \mathrm{~g} / \mathrm{pv}$ eli noin $20 \%$ rehuyksiköistä.

Koe 2 oli järjestetty saman periaatteen mukaan. Nollaryhmä sai jälleen pelkkää säilörehua (0), toinen ryhmä sai sakkaroosia $200 \mathrm{~g} / \mathrm{pv}$ (S) ja kolmas ryhmä vehnäntärkkelystä $200 \mathrm{~g} / \mathrm{pv}$ (T). Vastaava ry-määrä säilörehua vähennettiin $\mathrm{S}$ ja $\mathrm{T}$ ryhmien annoksista.

Lisäksi annettiin kivennäisseosta sekä $\mathrm{S}$ ja T ryhmissä $15.0 \mathrm{~g}$ kaseiinia/pv. Vettä oli vapaasti saatavilla.

Aineiston tilastollinen käsittely suoritettiin varianssianalyysillä $(3 \times 3)$.

\section{Kokeen kulku}

Pässit ruokittiin aamuin illoin. Säilörehu otettiin joka ruokintakerralla maatilan silosta ja keruukausien aikana siitä tehtiin joka kerta kuiva-ainemääritys. Samalla kuivattiin pieni erä vakuumissa $50^{\circ}:$ ssa analyysejä varten. Mahdolliset tähteet kuivattiin ja punnittiin päivittäin. Kaksi kolme kertaa keruukauden aikana määritettiin rehun tuorenäytteestä $\mathrm{pH}$, ammoniakkityppi ja orgaaniset hapot.

Pässien sontapussit tyhjennettiin ruokinnan yhteydessä illoin aamuin keruuastioihin, jotka säilytettiin yön yli $+4^{\circ} \mathrm{C}$ :ssa. Aamulla sonta punnittiin, hienonnettiin, kuivattiin analyysinäyte ja tehtiin kuiva-ainemääritys. Virtsa mitattiin illoin aamuin ja siitä otettiin tietty prosenttimäärä näytepulloon. Virtsankeruuastiassa oli tymolia estämässä mikrobitoimintaa.

Analyysinäytteet jauhettiin Wiley myllyllä seulaa no 40 käyttäen. 
Viralliseen rehuanalyysiin kuuluvat määritykset olivat tavanomaisia. Eri hiilihydraattiryhmät, raakaligniini ja orgaaniset hapot määritettiin SALon (1965, 1969) menetelmillä. Ammoniakkityppi määritettiin A.O.A.C. (1960 s. 285) menetelmällä.

Taulukko 1. Säilörehun keskimääräinen koostumuః eri koejaksoina. ${ }^{1}$ )

Table 1. Average composition of silage at various periods. ${ }^{1}$ )

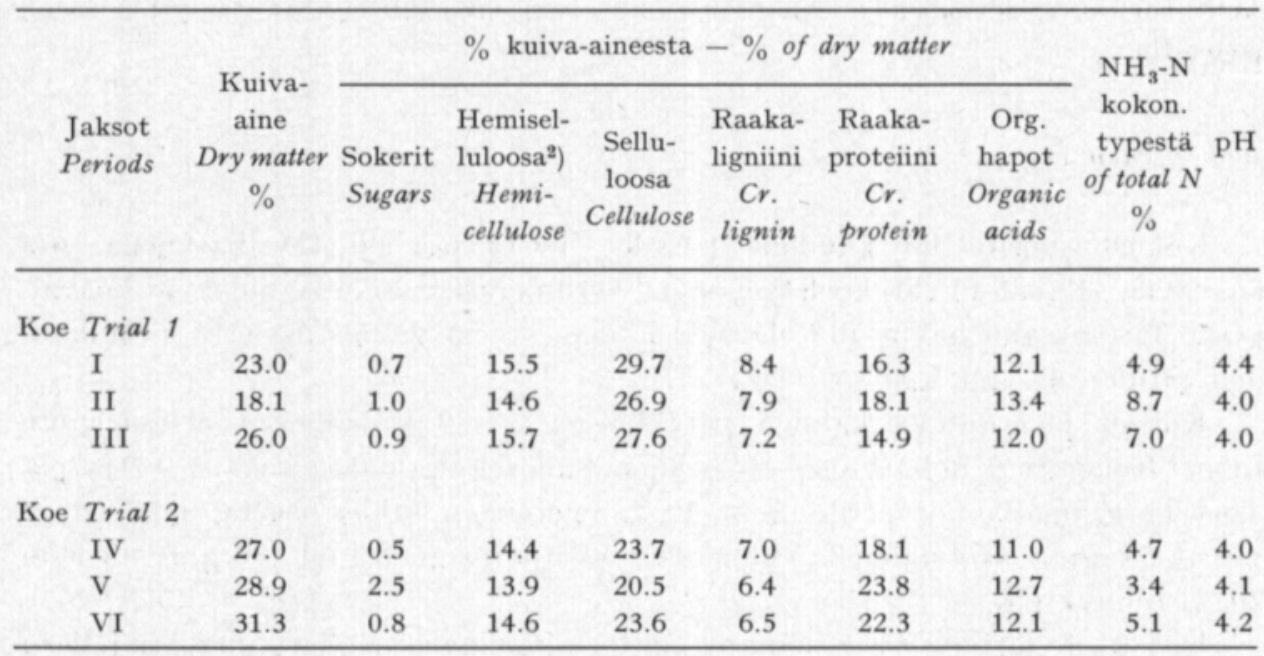

1) Raaka-aine ja valmistusaika: Jakso I, säilörehunurmi, 2. sato, elokuu. Jakso II, heinän odelma, syyskuu. Jaksot III-VI, laidunruoho, 1. sato, kesäkuu, esikuivattu $24-30 \%$ kuivaainepitoisuuteen.

1) Material and time of harvest: Period I, silage grass, 2. harvest, August. Period II, aftermath of hay, September, Periods III-VI, pasture grass, 1. harvest, Juni, wilted to $24-30 \%$ dry matter.

$\left.{ }^{2}\right)$ Vain sokerianhydridit - Sugar anhydrides only.

\section{Rehun koostumus}

Säilörehun koostumus eri keruukausina näkyy taulukosta 1. Rehu otettiin maatilan siilosta ja saatiin siten kokeeseen hyvälaatuisena, koska tilan käyttö oli suuri, mutta haittapuolena oli koostumuksen vaihtelu eri jaksoina. Kokeen 1 kahtena ensimmäisenä jaksona rehu oli niittotuoreena säilöttyä, kolmantena ja koko kokeen 2 ajan se oli lievästi esikuivattua kesäkuun satoa. Esikuivatus oli kuitenkin ollut niin lievä, että sokerit olivat käyneet hapoiksi ja pH sekä happopitoisuus oli samaa luokkaa kuin märässä rehussä. Laadullisesti rehu oli moitteetonta koko ajan.

Rehuyhdistelmien raakavalkuaispitoisuus eri koejaksoina käy ilmi taulukosta 2. 
Taulukko 2. Rehuyhdistelmien raakaproteiinipitoisuus, \% kuiva-aineesta.

Table 2. Crude protein content of rations, percentages of dry matter.

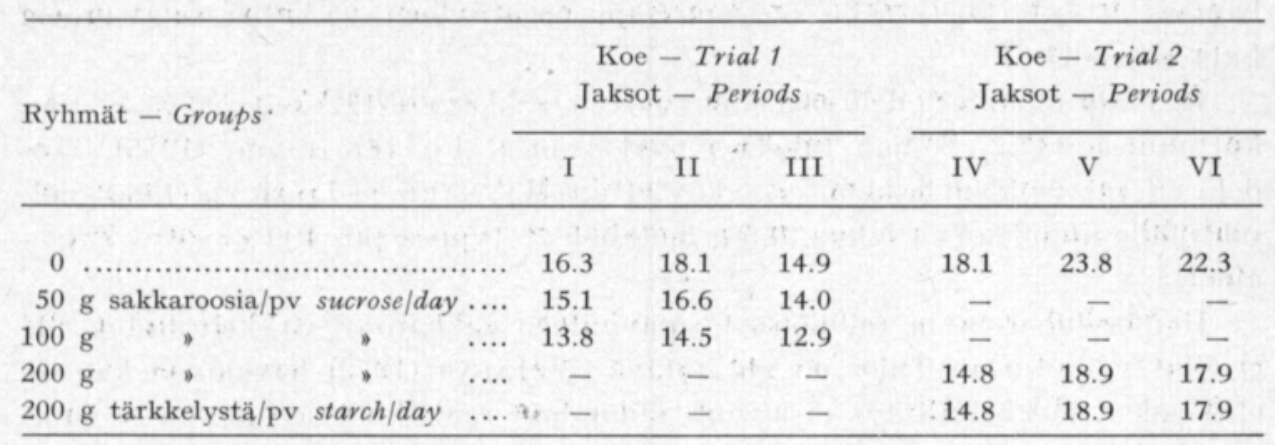

\section{Tulokset ja niiden tarkastelu}

Sulavuuskokeet

Kokeiden tulokset esitetään taulukossa 3. Luvut ovat kuuden eläimen keskiarvoja.

Taulukko 3. Säilörehun sulavuus (\%) pässeillä, jotka saivat eri suuria määriä sakkaroosia tai vehnän tärkkelystä.

Table 3. Digestibility coefficients of silage for sheep receiving different sucrose or wheat starch supplements.

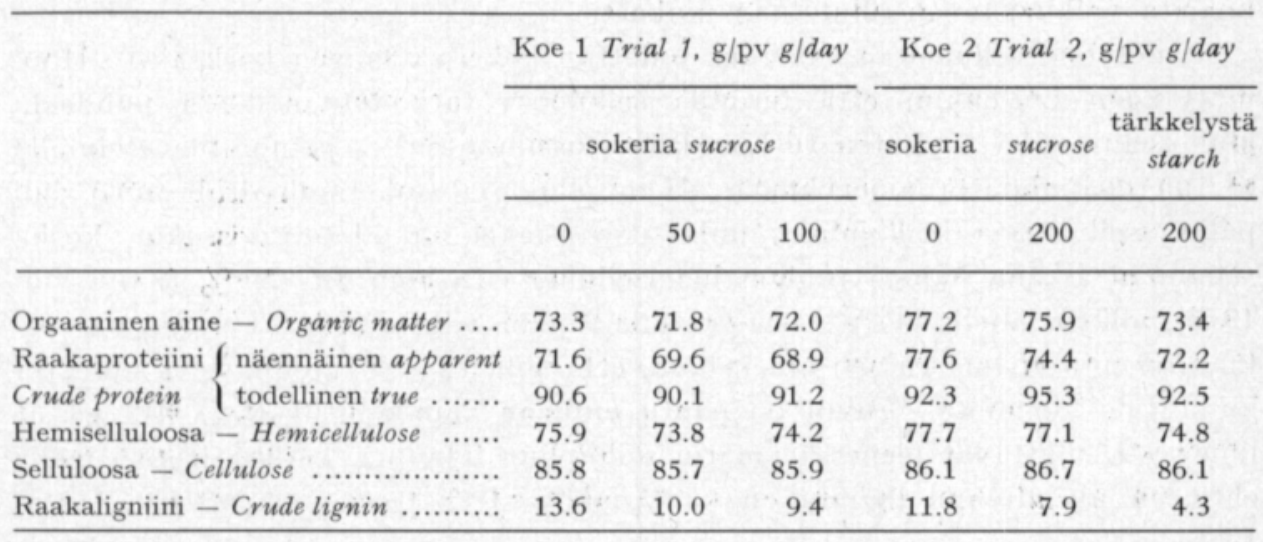

Ryhmien välillä ei ollut tilastollisesti merkitseviä eroja $(\mathrm{P}>0.05)$.

The differences between groups were not significant $(P>0.05)$.

Varianssianalyysi $(3 \times 3)$ osoițti, että sakkaroosilisäyksellä ei ollut vaikutusta säilörehun orgaanisen aineen sulavuuteen annettiinpa sitä $50 \mathrm{~g}, 100 \mathrm{~g}$ tai $200 \mathrm{~g}$ päivässä. Suunta oli laskeva, mutta ero merkityksettömän pieni ja sakkaroosimäärän lisäys ei suurentanut eroa.

Tärkkelyksellä oli ilmeinen sulavuutta alentava vaikutus, mikä ei kuitenkaan ollut tilastollisesti merkitsevä, koska eläinaines oli kovin epätasaista. Tärkkelyksen negatiivinen vaikutus tuli esille erikoisesti sulavuuden parane- 
misena, kun pässit siirtyivät tärkkelysdieetiltä nolla- tai sokeriryhmään. Tulos pitää yhtä SwIFT ym. (1947) ja PAndit ja Singhin (1969) havainnon kanssa, että tärkkelyksellä on suurempi negatiivinen vaikutus sulavuuteen kuin sokerilla.

Raakaproteiinin todelliseen sulavuuteen sakkaroosi/tärkkelyslisäys ei vaikuttanut mitään. Saman tuloksen ovat saaneet Fontenot ym. (1955). Todellisen sulavuuden laskemisessa käytettiin MAYNARD ja LoosLyn (1969) märehtijöille ilmoittamaa lukua, $0.5 \mathrm{~g}$ metabolista typpeä pro $100 \mathrm{~g}$ syötyä kuivaainetta.

Hemiselluloosan ja selluloosan sulavuuteen sakkaroosi/tärkkelyslisäyksellä ei ollut vaikutusta. Tulos on yhtäpitävä SYRJÄLÄn (1972) havainnon kanssa, että sokeri/tärkkelyslisäys ei alenna säilörehun rakakuidun sulavuutta juuri nimeksikään, vaikka se pienessä määrin alentaa orgaanisen aineen sulavuutta. Heinä-väkirehu dieeteillä on saatu päinvastaisiakin tuloksia (FonTENot ym. 1955, Woods ym. 1956).

Rehuyhdistelmän kokoonpano ilmeisestikin vaikuttaa sulavuuskokeiden tuloksiin. BurRoughs ym. $(1949,1950)$ mukaan dieetin proteiinipitoisuudella on selvä vaikutus: jos proteiinia on niukasti, perusrehun sulavuus alenee tärkkelystä lisättäessä jyrkästi, jos proteiinia on kohtuullisesti, aleneminen on vähäistä. Kirjoittajain tutkimuksessa proteiinia oli myös sokeri- ja tärkkelysdieeteissä verraten runsaasti (taul. 2), ei tosin kaikkina koejaksoina läheskään sitä määrää (18\%), minkä FREDERIKSEN (1971) ilmoittaa nurmirehujen sulavuuden kannalta optimiarvoksi. Kirjallisuuteen perehtyessä saa sen vaikutelman, että tulosten ristiriitaisuus johtuu ainakin osaksi siitä, että osassa kokeita valkuaista on ollut liian niukasti.

Säilörehun selluloosan sulavuus todettiin kokeissa sangen korkeaksi. Huomattakoon kuitenkin, että termillä selluloosa tarkoitetaan tässä puhdasta glukosaania eikä - kuten tutkimuksissa useimmiten - jäännösmenetelmällä saatua epäpuhdasta aineryhmää. Hemiselluloosa (sokerianhydridiosuus) suli paljon selluloosaa heikommin, mikä itse asiassa on odotettavissakin, koska säilönnän aikana hajoaa ruohon hemiselluloosasta noin $10-30 \%$ (SALO ym. 1972), jolloin jäljelle jää pääasiassa vaikealiukoista ksylaania. Ligniini vuorostaan on niin epämääräinen aineryhmä, että siihen ei vertailumielessä kannata kiinnittää huomiota. Luvut on pantu mukaan vain osoitukseksi, että pässit ilmeisesti sulattavat pienessä määrin säilörehun ligniiniä, vaikka heinäasteelle ehtineen nurmirehun ligniini on käytännöllisesti katsoen sulamatonta (SALO 1965).

Kokeessa pantiin merkille selvä maittavuusero märän ja esikuivatun säilörehun välillä. Kokeen 1 kahtena ensimmäisenä jaksona pässit jättivät tähteitä, mutta kun siirryttiin esikuivattuun rehuun, tähteitä ei jäänyt. Huonosti maittava rehu myös suli hyvin maittavaa heikommin, kuten taulukosta 3 voidaan todeta.

\section{Typpitasekokeet}

Kokeen 2 aikana suoritettiin typpitasekoe, joskin ennakkoon voitiin laskea että vain keskiarvotuloksilla on vertailuarvoa, koska kaksi pässiä oli kasvavia, 
loput neljä täysikasvuisia. Säilörehu oli koko ajan maittavaa, energiansaanti oli yli ylläpitotarpeen ja pässit lihoivat. $\mathrm{S}$ ja $\mathrm{T}$ ryhmän eläimet saivat valkuaistäydennykseksi $15.0 \mathrm{~g}$ kaseiinia päivässä. Kaseiinin sulavuus laskettiin taulukkotietojen mukaan.

Taulukko 4. Typpitaseet kokeessa 2.

Table 4. Nitrogen balances in trial 2.

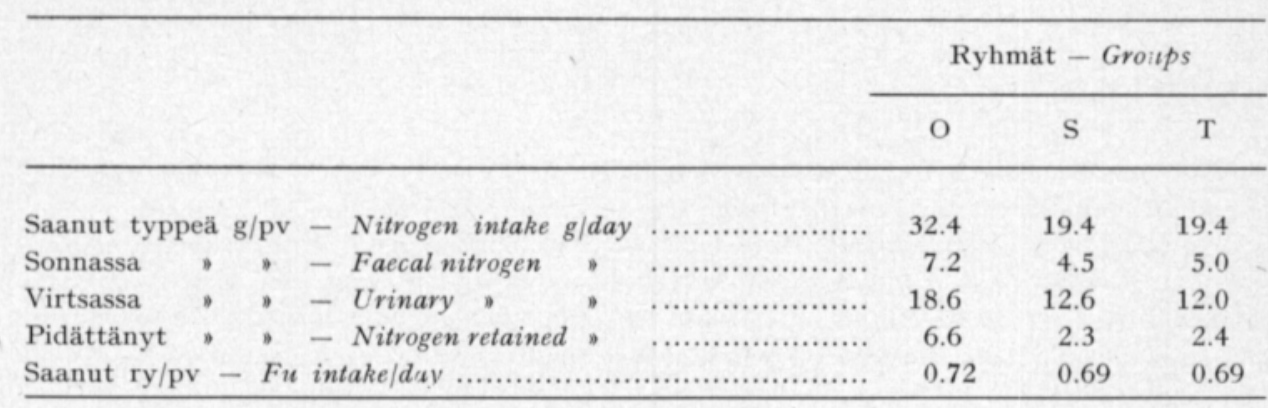

Ryhmien välillä ei ollut tilastollisesti merkitseviä eroja $(\mathrm{P}>0.05)$.

The differences between groups were not significant $(P>0.05)$.

Tasekokeen tulokset kolmen jakson eli yhteensä kuuden pässin keskiarvoina esitetään taulukossa 4. Siitä käy ilmi, että nollaryhmä pidätti typpeä enemmän kuin sokeri- ja tärkkelysryhmät, joskaan ero ei ollut tilastollisesti merkitsevä. Sokeri- ja tärkkelysryhmät olivat keskenään aivan tasaveroisia. Nollaryhmä sai energiaa hiukan enemmän kuin $\mathrm{S}$ ja $\mathrm{T}$ ryhmät $(0.03$ ry/pv), mutta määrä on liian pieni selittämään typen pidättymisen eroa. Raakavalkuaisen saannissa ero oli suuri, mutta silti myös $S$ ja T ryhmät saivat n. $80-100 \mathrm{~g} \mathrm{srv} / \mathrm{pv}$, mikä määrä hyvin vastasi energiatason sallimaa typen pidättymistä. Kuten kirjallisuusosasta kävi ilmi, on sokeri- ja tärkkelyslisän harvoja poikkeuksia lukuunottamatta (DroR ym. 1969, SYRJÄLÄ 1972, tärkkelyskokeet) todettu parantavan typpitasetta.

\section{Yhteenveto}

Sokeri- ja tärkkelyslisäyksen vaikutusta säilörehun sulavuuteen tutkittiin kuudella pässillä, joista kaksi oli kasvavaa, neljä täysikasvuista. Koe oli järjestetty kahden peräkkäisen $3 \times 3$ latinalaisen neliön muotoon. Kokeessa 1 lisättiin dieettiin $0,50 \mathrm{~g}$ tai $100 \mathrm{~g}$ sakkaroosia/eläin/pv. Kokeessa 2 lisäys oli $0,200 \mathrm{~g}$ sakkaroosia tai $200 \mathrm{~g}$ vehnäntärkkelystä/eläin/pv. Vastaava ry-määrä säilörehua vähennettiin. Hiilihydraattilisäykset vastasivat noin 10, 20 ja $40 \%$ nettoenergiasta. Pässit saivat lisäksi kivennäistä ja 200 g:n lisäaineryhmät kaseiinia $15.0 \mathrm{~g} / \mathrm{pv}$. Kokeen 1 dieetit sisälsivät raakavalkuaista noin $13-18$ $\%$, kokeen $215-24 \%$ k.a:sta. Energiansaanti oli vähän yli ylläpitotarpeen.

Sakkaroosi ei vaikuttanut käytännöllisesti katsoen mitään säilörehun orgaanisen aineen, hemiselluloosan, selluloosan eikä raakaproteiinin todelliseen sulavuuteen annettiinpa sitä 50, 100 tai $200 \mathrm{~g} / \mathrm{pv}$.

Tärkkelyksellä todettiin pieni sulavuutta alentava vaikutus, mikä ei kuitenkaan ollut tilastollisesti merkitsevä. 
Kokeessa 2 määritettiin myös typpitase. Sekä sakkaroosi- että tärkkelys alensi vähän, joskaan ei merkitsevästi, typen pidättymistä. Keskenään sakkaroosi ja tärkkelys olivat tässä kohden samanarvoisia.

\section{KIRJALL ISUUTTA}

Burroughs, W., Gerlaugh, P., Edgington, B. H. \& Bethge, R. M. 1949. The influence of corn starch upon roughage digestion in cattle. J. Anim. Sci. 8: 271-278,

- - Gall, L. S., Gerlaugh, P., Bethge, R. M. 1950. The influence of casein upon roughage digestion in cattle with rumen bacteriological studies. J. Anim. Sci. 9: 214-220.

Chappell, G. L. M. \& Fontenot, J. P. 1968. Effect of level of readily-available carbohydrates in purified sheep rations on cellulose digestibility and nitrogen utilization. J. Anim. Sci. 27: 1709-1715.

Dror, Y., MAYEvSKy, A. \& Bondi, A. 1969. Some affects of starch on protein utilization by sheep. Brip. J. Nutr. 23: 727-735.

Fontenot, J. P., Gallup, W. D. \& Nelson, A. B. 1955. Effect of added carbohydrate on the utilization by steers of nitrogen in wintering rations. J. Anim. Sci. 14: 807-817.

Frederiksen, J. H. 1971. Protein- und Melasseeinfluss auf die in vitro Verdaulichkeit. Wirtschaftseig. Futter 17: $295-303$.

Hamilton, T. S. 1942. The effect of added glucose upon digestibility of protein and of fiber in rations for sheep. J. Nutr. 23: 101-110.

HEAD, M. J. 1953. The effect of quality and quantity of carbohydrate and protein in the ration of the sheep on the digestibility of cellulose and other constituents of the ration, with a note on the effect adding vitamins of the B-complex on the digestibility and retention of the nutrients of the hay ration. J. Agric. Sci. 43:281-293.

Martin, R. J. Jr. \& Wing, J. M. 1966. Effect of molasses level on digestibility of a high concentrate ration and on molar proportions of volatile fatty acids produced in the rumen of dairy steers. J. Dairy. Sci. 49: 846-849.

Maynard, L. A. \& Loosly, J. K, 1969. Animal nutrition. New York 1969, p. 142.

PANDIT, N. N. \& Singh, S. N. 1969. Factors affecting crude fibre utilization in ruminants. Nutr. Abstr. Rev. 39: 3780.

SALO, M.-L. 1965. Determination of carbohydrate fractions in animal foods and faeces. Acta Agr. Fenn. 105: 1-102.

- - - \& Kotilainen, K. 1969. Determination of free and combined plant acids. J. Sci. Agric. Soc. Finl. 41: 277-289.

- - Sormunen, R. \& IMmonen, M. 1972. Esikuivatussa ja niittotuoreessa säilörehussa tapahtuvat ravinnetappiot. Koetoim. ja Käyt. 29: 15-16.

Swift, R. W., Thacker, E. J., Black, A., Bratzler, J. W. \& James, W. H. 1947. Digestibility of rations for ruminants as affected by proportions of nutrients. J. Anim. Sci. 6: $432-444$

SYRJÄLÄ, L. 1972. Effect of different sucrose, starch and cellulose supplements on the utilization of grass silages by ruminants. Ann. Agric. Fenn. 11: 199-276.

VARNER, L. W. \& Woods, W. 1972. Effect of calcium and starch additions upon ration digestibility by steers. J. Anim. Sci. 35: 410-414.

Watson, C. J., Davidson, W. M., Kennedy, J. W., Robinson, C. H. \& Muir, G. W. 1949. Digestibility studies with ruminants. XIV. The effect of the plane of nutrition on the digestibility of barley. Sci. Agric. 29: 400-407.

Woods, W. R., Thompson, C. M. \& Grainger, R. B. 1956. The effect of varying levels of protein and cerelose on the utilization of mature timothy hay by sheep. J. Anim. Sci. 15: $1141-1146$. 